\title{
Text-based Computer-mediated Discourse Analysis: What Causes an Online Group to Become a Virtual Community?
}

\author{
Qiuna $\mathrm{Li}^{1}$ \\ ${ }^{1}$ School of English Education, Guangdong University of Foreign Studies, Guangzhou, China \\ Correspondence: Qiuna Li, School of English Education, Guangdong University of Foreign Studies, 178, Waihuan \\ Donglu, Guangzhou Higher Education Mega Center, Guangzhou 510006, China.
}

Received: April 2, 2020

doi:10.11114/ijsss.v8i4.4867
Accepted: April 20, $2020 \quad$ Available online: May 20, 2020

URL: https://doi.org/10.11114/ijsss.v8i4.4867

\begin{abstract}
The present study seeks to explore how computer-mediated discourse analysis can be useful for the study of online interaction, in particular, text-based multiparty interaction. The data are from the text-based chat group of high school English language teachers in China, which consists of more than one thousand members. Because of the fluid membership, reduced social accountability, and lack of shared geographical space, it seems that not every online group automatically becomes a "community". Addressing this concern, and informed by the computer-mediated discourse analysis (CMDA) proposed by Herring, the researcher seeks to investigate the properties of virtual communities and to assess the extent to which they are realized by specific online groups.
\end{abstract}

Keywords: CMDA, online interaction, virtual community, discourse

\section{Introduction}

This article is an investigation into patterns of interaction and relationship management in synchronous, text-based computer-mediated communication (henceforth CMC), aiming to contribute to an understanding of the extent to which human interaction is affected and shaped by mediation via computers. Every one of us lives in a world where we experience different social encounters, where social interaction is the basis of its running (Tan \& Tan, 2006). Interaction is not simply a way to exchange information but also a way to build "social ties" and (re)define the "nature of social life" (Mesthrie, 2011, p. 113). Therefore, participation in interaction can be viewed as "participation in social action" (Goffman, 1967, p. 52) and a means of socializing with others (Gordon, 2004; Tannen, 2005).

In the past decades, with the increasing digitalization, the Internet has triggered various ways of online interaction, for example, chat rooms, Web forums, email, instant messaging environments, such as MSN, Skype, QQ, and WeChat. Thus, with the development of the Internet and the emergence of the smart-phone, social messengers or social messaging applications have grown into a global phenomenon in people's daily life (Tsai \& Men, 2018). Online communication allows people to share ideas, hold each other's attention (Lipinski-Harten \& Tafarodi, 2013), build an alliance and form a kind of visual community (Tan \& Tan, 2006).Moreover, social messengers provide a portable, interactive, and user-controlled communication platform with multimedia features such as text, hold-to-talk voice, group chat, video calls, message notifications, status updates, and media sharing (Wu, 2014). Despite the availability of multimedia functions, such as audio and video interfaces, most online communicators opt for text-based communications that require "less scrutiny of the other, less self-exposure, and less sustained attention" (Lipinski-Harten \& Tafarodi, 2013, p. 2490). This kind of text-only environment allows communicators to focus more on their intentions, desires, and beliefs (Suler, 2004). Hence, textual communication remains an important online activity today, and one that seems "destined to continue for the foreseeable future" (Herring, 2004, p. 338).

Furthermore, the emergence of new communication technologies and the corresponding establishment of computer-mediated communication (CMC) have triggered a growing interest in the large variety of electronic communication, from email to online discussion, from multiplayer interaction to the online community (Herring, 2010). In particular, some researchers have moved increasingly away from the study of exclusively online data to focus more on Internet use as a situated social activity (Giles, et al., 2015), more specifically, to the ethnography (Georgakopoulou, 2006) or netnography (Kozinets, 2010) of computer-mediated discourse (CMD). As Herring and Androutsopoulos (2015) note, "the social aspects of CMD are shaped by the progressive digitization of society and the embedding of 
digital communication technologies in everyday life" (p. 138), and the very distinction between offline and online communication is now increasingly fuzzy, as people are "always on" (Baron, 2008). Thus, the author argues that it is necessary and valuable to pay attention to CMD, i.e. digital discourse, and to what happens online. For this purpose, informed by computer-mediated discourse analysis (Herring, 2004) and from an interactional sociolinguistic perspective, the researcher chooses the online group of professionals as an analytical objective to give insight into the online communications.

Following a netnographic approach, the researcher extracted the dataset of one High School EFL Teachers Group of China (Henceforth EFL-TG) on QQ, the biggest online instant message system in China, to explore how a virtual community formed in social media. The researcher uses the text-based interactions during half a year in EFL-TG on QQ as corpora to find out the discourse evidence. The present study was guided by the following two research questions:

1) What are the discourse characteristics of a virtual community?

2) What causes an online group to become a community?

\section{Theoretical Background}

\subsection{Computer-Mediated Discourse}

According to Herring and Androutsopoulos (2015), computer-mediated discourse is communication that emerged when human beings interact with one another by transmitting messages via networked or mobile computers, where "computers" are defined broadly to include any digital communication device, such as pad, smart-phone. In other words, any analysis of online behavior that is grounded in empirical, textual observations is computer-mediated discourse analysis (Herring, 2004). Besides, the study of CMD is a specialization within the broader interdisciplinary study of computer-mediated communication, distinguished by its "focus on language and language use" and by its use of methods of discourse analysis to address that focus (Herring, 2019, p. 25). Originally, most CMC was text-based, including email, discussion forums, chat, blogs, micro-blogs, however, with the development of Web 2.0 platforms and smart-phones, textual CMC has been supplemented by graphical, audio, and video channels of communication. All of these environments provide rich contexts "in which to observe verbal interaction and the relationship between discourse and social practice" (Herring \& Androutsopoulos, 2015, p. 127).

CMDA was first conceptualized in 1994 and developed by Herring as a paradigm over the subsequent decade (Herring, 2004, 2019). By 2004 it had evolved into a "methodological toolkit" (see Table 1) organized around "four linguistic levels: structure, meaning, interaction management, and social behavior, reflecting a progressive broadening of focus from the micro (structure) to the macro (social) level" (Herring, 2019, pp. 26-27). As Table 1 shows, the structural level includes the use of special typography or orthography, novel word formations, and sentence structure. The meaning level includes the meanings of words, utterances, and larger functional units. The interactional level includes turn-taking, coherence, threads, and other means of negotiating interactive exchanges. The social level includes linguistic expressions of play, conflict, power, identity, group membership, and community.

Table 1. The computer-mediated discourse analysis "toolkit" (Herring, 2019, pp. 26-27)

\begin{tabular}{|c|c|c|c|}
\hline Levels & Issues & Phenomena & Methods \\
\hline Structure & $\begin{array}{l}\text { Orality, formality, efficiency, } \\
\text { expressivity, complexity, } \\
\text { genre, etc. }\end{array}$ & $\begin{array}{l}\text { Typography, orthography, } \\
\text { morphology, syntax, discourse } \\
\text { schemata, formatting conventions, } \\
\text { etc. }\end{array}$ & $\begin{array}{l}\text { Structural/ descriptive linguistics, text } \\
\text { analysis, corpus linguistics, stylistics }\end{array}$ \\
\hline Meaning & $\begin{array}{l}\text { What is communicated? } \\
\text { What is intended? } \\
\text { What is accomplished? }\end{array}$ & $\begin{array}{l}\text { Meaning of words, utterances (speech } \\
\text { acts), exchanges, etc. }\end{array}$ & Semantics, pragmatics \\
\hline $\begin{array}{l}\text { Interaction } \\
\text { management }\end{array}$ & $\begin{array}{l}\text { Interactivity, timing, } \\
\text { coherence, repair, interaction, } \\
\text { etc. }\end{array}$ & $\begin{array}{l}\text { Turns, sequences, exchanges, threads, } \\
\text { etc. }\end{array}$ & $\begin{array}{l}\text { Conversation analysis, } \\
\text { ethnomethodology }\end{array}$ \\
\hline $\begin{array}{l}\text { Social } \\
\text { phenomena }\end{array}$ & $\begin{array}{l}\text { Social dynamics, power, } \\
\text { identity, community, cultural } \\
\text { differences, etc. }\end{array}$ & $\begin{array}{l}\text { Linguistic expressions of status, } \\
\text { conflict, negotiation, face } \\
\text { management, play, discourse styles, } \\
\text { etc. }\end{array}$ & $\begin{array}{l}\text { Interactional sociolinguistics, critical } \\
\text { discourse analysis, ethnography of } \\
\text { communication }\end{array}$ \\
\hline
\end{tabular}

Chronologically, Herring (2019) divides the development of CMDA into three historical phases: pre-Web, Web 1.0 and Web 2.0. During Phase One, pioneering scholars first began addressing language use in CMC, and their studies mainly focused on the linguistic level, such as the influence of CMC systems on message sequences and turn-taking (Cherny, 1999), the classification of CMC concerned with speech and writing (Baron, 1998). CMDA as a paradigm emerged at 
the end of this phase. During Phase Two, with the development of the World Wide Web, new modes of CMC emerged, such as wikis, weblogs, chat client ICQ, instant messaging and SMS. The rapid development of website triggered CMC research, many researchers focused on identity issues (Greenfield \& Subrahmanyam, 2003), online community (Cherny, 1999), addressing issues such as turn-taking, disrupted adjacency, topic development (e.g., Herring, 1999; Schönfeldt \& Golato, 2003). During the third Phase, CMDA has become more popular and rapidly developed, at the same time CMDA itself is being challenged to expand and adapt in various ways. In addition, numerous studies have addressed online behaviors from different perspectives, such as politeness (Graham, 2007), participation in CMC (Marcoccia, 2004), humor (Nishimura, 2012). Phase Three has witnessed increasing recognition for and use of, the CMDA paradigm.

In research practice, CMDA paradigm has been widely used in related areas: at the micro linguistic level, such as stance taking (Champeon, 2010), turn units (Condon \& Čech, 2001), coherence of exchanges (Herring, 1999), conversational floors (Simpson, 2005), quoting or retweet strategies in multiparticipant asynchronous CMD; at the macro sociocultural level, such as (im)politeness (Locher \& Watts, 2005; Planchenault, 2010), educational community of practice (Stommel, 2008), online identity construction (Bolander \& Locher, 2010).

In summary, as Herring (2004) states, CMDA is not a single method but rather a set of methods from which researchers could select those best suited to their data and research questions, which provides "a methodological toolkit and a set of theoretical lenses" to research online behavior (p. 341). Thus, through CMDA the researcher makes observations and interprets the results of empirical analysis. Informed by CMDA, the present study specifically focuses on the turns and threads to explore how an online group becomes a virtual community through day-to-day interactions of members.

\subsection{Online Community}

The concept of "Online community" has become increasingly fashionable in Internet research during the second Phase of CMDA, i.e. since the end of the last century. For some writers, it seems that any online group automatically becomes a "community", while others think that not all the online group can constitute a community because of the "fluid membership, reduced social accountability" (Herring, 2004, p. 343). Likely, the researcher assumes that an online group constitutes online virtual community based on some criteria. The concept of Community is inherently abstract, which has also a subjective component when it is applied to online contexts (Herring, 2004). According to Eckert and McConnell-Ginet (1992), a community of practice is "an aggregate of people who come together around mutual engagements in an endeavor", thus, their ways of doing and talking, beliefs, values, power relations "emerge in the course of this mutual endeavor" (p. 464). Similarly, Wenger (1998) describes three dimensions of the relation by which practice is the source of coherence of a community: mutual engagement, a joint enterprise, and a shared repertoire.

Based on previous literature on virtual community, Herring (2004, pp. 351-352) operationalizes the concept of virtual community as six sets of observable criteria, which could be objectively assessed, they are:

1) active participation and a core of regular participants (which can be measured over time and based on the frequency of posting and rate of response to messages posted);

2) shared history, culture, norms and values (which can be assessed through the choice of language, verbal reactions, etc.);

3) solidarity, support, reciprocity (which can be measured through the use of verbal humor, speech act analysis, analysis of turn initiation and response respectively);

4) criticism, conflict, means of conflict resolution (which can be analyzed through speech acts);

5) self-awareness of group as an entity distinct from other groups (which can be manifested in its members' references to the group as a group, for example, in "us vs them" language);

6) the emergence of roles, hierarchy, governance, rituals (which can be assessed through participation patterns and speech act analysis).

Guided by these six criteria summarized by Herring, the researcher seeks to explore whether the professional online group of EFL teachers can be called a "virtual" or an "online" community.

\section{Methodology}

\subsection{Participants}

The QQ group under this study, namely High School EFL teachers of China, was established in November of 2015 and was consisted of 1119 members (in July 2019 it already includes 1141). Participation is entirely free and voluntary, which needs the approval of the administrator of this group. The group is active and on average there are more than 50 messages posted online every day. The researcher of this study, as a pre-service high school EFL teacher, has been a 
member of this online group since October 2018, even if not as a pro-active member.

\subsection{Data Collection and Corpus Description}

The data was collected following a netnographic approach, which was defined as "a participant-observational research-based in online fieldwork [which] uses computer- mediated communications as a source of data to arrive at the ethnographic understanding and representation of a cultural or communal phenomenon" (Kozinets, 2010, p. 60). The data was collected from 1st January of 2019 to 30th June of 2019. Finally, a corpus of multiparty interaction texts was compiled, which involves 88107 _words and 4622 conversational turns in Chinese. In contrast with the "transparency" of face-to-face interaction, under the background of purely text-based exchanges and as well as anonymity, online communicators feel free to express their own beliefs, intentions, and desires. Hence, to some extent, the data collected online allow us to avoid the "observer paradox" (Labov, 1972).

\subsection{Ethics}

As Mann and Stewart (2000) state, CMC offers more advantages regarding data collection, which "results in the immediate production of a text file" (p. 22). Although some researchers indicate that messages posted on the internet are considered as public acts, there is no need to take more than "normal precautions" (Paccagnella (1997). However, texts need to be slightly edited to respect the group members' anonymity and to protect their privacy.

\subsection{Data Analysis}

Analytical methods in CMDA are drawn from discourse analysis and other language-related paradigms, adapted to address the characteristics of computer-mediated communication (Herring, 2004). To answer the two research questions of this study, the researcher conducted data analysis based on Herring's (2004) summary of discourse behaviors hypothesized to indicate a virtual community, which was illustrated in Table 2. It is consistent with Herring (2004) that an investigation attempting to address all of the discourse behaviors in Table 2 would probably not be feasible. Therefore, the researcher, following Stommel (2008), conducted an interactional sociolinguistic analysis which can reveal various dimensions or aspects of interaction and facilitate addressing the interpretative challenges mentioned by Herring.

Table 2. Discourse behaviors hypothesized to indicate virtual community (Herring, 2004)

\begin{tabular}{ll}
\hline \multicolumn{1}{c}{ Levels } & \multicolumn{1}{c}{ Issues } \\
\hline structure & jargon, references to group, in-group/ out-group language \\
meaning & exchange of knowledge, negotiation of meaning (speech acts) \\
interaction & reciprocity, extended (in-depth) threads, core participants \\
social behavior & solidarity, conflict management, norms of appropriateness \\
participation & frequent, regular, self-sustaining activity over time \\
\hline
\end{tabular}

Interactional sociolinguistic was defined as "the search for replicable methods of qualitative analysis that account for our ability to interpret what participants intend to convey in everyday communicative practice" (Gumperz, 2003, p. 4), which has its origin "in the ethnography of communication, conversation analysis, ethnomethodology, Goffman's work on face and Grice's principles of conversational cooperation" (Wardhaugh \& Fuller, 2015, p. 291). As Couper-Kuhlen and Selting (2017) state, interactional sociolinguistic methodology "establishes a link between the sequential analysis of naturally occurring talk in everyday interaction", and "a linguistic analysis of the rhetorical, lexico-semantic, segmental-phonetic, and vocal-prosodic means mobilized in such sequences" (p. 15). From this perspective, data should be analyzed as an integral part of the sequential conversational context in which they occur (Couper-Kuhlen \& Selting, 2017). Thus, as Sacks, Schegloff and Jefferson (1974) stress, through the sequential organization of interaction participants display to each other their understanding of prior turns in the next turns.

To find out the discourse features of this High School EFL teachers Group, the researcher has paid special attention to the turns and threads. Turn-taking is not random, rather, it has structure and is representative of a system (Tan \& Tan, 2006). Given that turn-taking is the basic form of organization for a conversation (Tan \& Tan, 2006), the researcher argues that it is necessary to conduct the data analysis from the turns to identify the discourse features in an online environment. Informed by interactional linguistics, to identify the discourse characteristics of the group interaction, the researcher follows a four-stage analysis procedure (see figure 1). As figure 1 shows, the analysis procedure includes the following four steps: identifying main features of turn-taking, analyzing emerging conversational floor, 
content-sensitive analysis of topic development, and coding and presenting categories devised for each criterion.

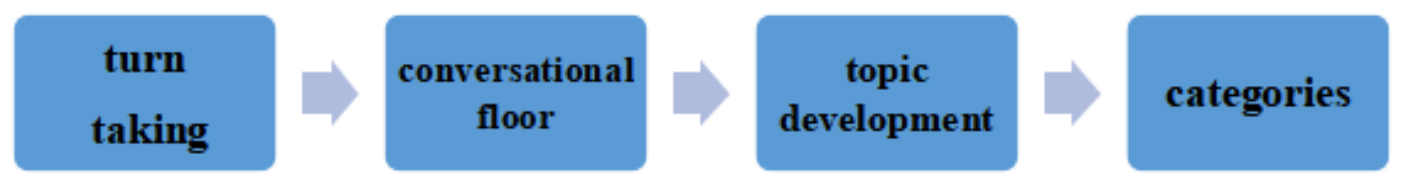

Figure 1. Analysis procedure

\section{Results}

\subsection{Discourse Features of Online Interaction within Group}

\subsubsection{Disrupted Turn Adjacency}

Data collected in this study involve 4622 conversational turns. Sacks, Schegloff, and Jefferson's (1974) model of turn-taking focuses on two components: the "turn-constructional component" based on the speaker's choice of turn-taking unit-types, and the "turn-allocational component" based on how a participant takes the next turn (p. 12). Sacks, Schegloff, and Jefferson (1974) note that turns in the talk can be constructed out of four units of talk: (a) one word, (b) a phrase, (c) a clause, or (d) a sentence. The data analyzed for this study reveal that most of the turns were constructed out of complete sentences.

In comparison to the spoken conversation, written conversation display a reduced sensitivity to the coordination of transfer in turn-taking. A token of the lack of cohesion in turn-taking - what Herring (1999) calls the lack of sequential coherence - is the resultant disrupted turn adjacency. Example 1 is a typical instance of disrupted turn adjacency. Here and in subsequent examples, turns have been numbered for ease of reference.

In the stretch of text in example 1, turn 1 was followed by unrelated turns (turns 2 and 3), which were seen as disrupted turn adjacency. While turns 4 and 5 follow the pattern of an adjacency pair (Schegloff \& Sacks, 1973). In an adjacency pair, the relationship between the first and second pair parts is one of conditional relevance. However, although the response is expected, or conditionally relevant, it is not as expected (or preferred) as a response such as "Yes, you are right". Furthermore, Wang tried to keep the cross-turn coherence of the interaction through using "@”.

Example 1 (18th January 2019)

\begin{tabular}{|c|c|c|c|}
\hline Turn & Time & Message & Translation \\
\hline 1 & $5: 43$ & $\begin{array}{l}\text { Bai: 振兴教育不在房子, 在于老师。物质不是最 } \\
\text { 主要的, 人才是最主要的, 人类灵魂的工程师应 } \\
\text { 该得到尊重, 这个国家才有希望。 }\end{array}$ & $\begin{array}{l}\text { Bai: The development of education doesn't lie in houses, but } \\
\text { teachers. The most important thing is not material but talented. } \\
\text { The engineer of the human soul should be respected, only in this } \\
\text { way the country will be stronger. }\end{array}$ \\
\hline 2 & 8:03 & $\begin{array}{l}\text { Bradley: 分享《英语美文欣赏》, 保存起来, 很棒 } \\
\text { 的资料。 }\end{array}$ & $\begin{array}{l}\text { Bradley: I'm sharing the Appreciation of English Literature. Very } \\
\text { good material, keep it. }\end{array}$ \\
\hline 3 & $12: 34$ & $\begin{array}{l}\text { Jane: 请问哪位老师有《中国新年》双语字幕版, } \\
\text { 能分享一下吗? }\end{array}$ & $\begin{array}{l}\text { Jane: Who has the video of Chinese New Year with bilingual } \\
\text { subtitles? Can you share it? }\end{array}$ \\
\hline 4 & 13:00 & $\begin{array}{l}\text { Wang: @Bai 感觉压力很大,如何把学生教好！一 } \\
\text { 点信心都没有! }\end{array}$ & $\begin{array}{l}\text { Wang: @Bai I feel so stressed. How to teach students well? No } \\
\text { confidence at all! }\end{array}$ \\
\hline 5 & 13:02 & Bai: @Wang 在北京都是家长压力太大 & Bai: @Wang It is the parents who feel stressed in Beijing. \\
\hline 6 & 13:02 & Bai: 家长忙着补课给孩子 & Bai: Parents are busy with tutoring their children. \\
\hline 7 & 13:03 & $\begin{array}{l}\text { Bai: 我女儿五年级了今天期末考试, 语文考了一 } \\
\text { 张前几天做了三次的卷子, 老师说, 孩子们考的 } \\
\text { 都很好 }\end{array}$ & $\begin{array}{l}\text { Bai: My daughter is in the fifth grade. Today she attended the } \\
\text { final exam. The teacher said that the children did well in the } \\
\text { exam. But the paper was done for three times before that. }\end{array}$ \\
\hline
\end{tabular}

8 13:05 Bai: 我一点也不高兴, 这是考试吗?

Bai: I'm not happy at all. Is this an exam?

9 13:07 Wang:真心不容易!

Wang: It's not easy, sincerely! 
10 13:08 Bai:从小学就开始忙于各种补习班

11 14:58 Rou: @Bradley 需要登录学科网才能下载?
Bai: The children are busy with all kinds of tutoring.

Rou: @Bradley Do we need to log in XUEKE website to download the material?

12 14:59 Wan:@Bai 北京考试都有欺骗行为? 又不是私立 学校

Wan: @ Bai A
private school.

13 15:23 Bai: @Wan 私立家长是上帝, 谁敢得罪, 公立你 爱上不上, 谁理你

Bai: @Wan For the private school parents are God, who dares to offend? But for the public school, who cares whether you go or not?

15:36 Bai:所以教育一定是要最优秀的人培养出更优秀 的人

Bai: For education, it must be that the most excellent people educate even more excellent.

15 15:44 Wan: 最优秀的人不愿意当老师

16 15:46 Bradley: @Rou 如需要就注册, 不花钱的

17 15:49 Megan: @ Bradley 真的非常感谢!!!

18 16:11 Homer：BBC 中国新年链接 https://pan.baidu.com/s/1hrH9a9u @ Jane 看链接 Wan: But the most excellent wouldn't be teachers. Bradley: @Rou If need, then please log in, it's free. Megan: @Bradley Thanks, thank you very much!!! Homer: Here is the link for Chinese New Year https://pan.baidu.com/s/1hrH9a9u @ Jane Check the link.

18 17:24 Jane: @ Homer 非常感谢! Jane: @Homer Thank you very much!

20 17:45 Bai: @Wan 那也不一定 Bai:@Wan That's not necessarily true.

21 20:45 Zhao: @Wang 在这样应试为主的大环境下, 恐怕 每个老师都有同感。
Zhao: @Wang In such an exam-oriented environment, I'm afraid every teacher has the same feeling.

Besides, turn-taking in CMC does not adhere to the idea that the speaker turns alternate in an orderly fashion. As example 2 shows, there is not a one-to-one correspondence between initiation and its response. Multiple responses (e.g. from turn 2 to turn 9) are directed at a single initiating message (turn 1). Moreover, some initiations receive no response, especially the initiation happened when a topic was discussed by multiple participants. As example 2 shows, in turns 10 and 11 Yang initiated a new topic when the other participants were talking about "100 days countdown of college entrance examination". Although Yang sent two messages with a clear explanation of her attempt, she did not receive any response from other participants. Besides, the next adjacency pair (turn 12) was responded to the first turn.

The fact that turn-taking is significantly disrupted even in relatively "coherent" samples such as these (e.g. example 2) suggests that disruption of turn-taking is a real and persistent phenomenon in CMC. In addition, turn-taking in CMC does not adhere to the idea that the speaker turns alternate in an orderly fashion. As example 2 shows, there is not a one-to-one correspondence between initiation and its response. Multiple responses (e.g. from turn 2 to turn 9) are directed at a single initiating message (turn 1). Moreover, some initiations receive no response, especially the initiation happened when a topic was discussed by multiple participants. As example 2 shows, in turns 10 and 11 Yang initiated a new topic when the other participants were talking about "100 days countdown of college entrance examination". Although Yang sent two messages with a clear explanation of her attempt, she did not receive any response from other participants. Besides, the next adjacency pair (turn 12) was responded to the first turn. 
Example 2 (26th February 2019)

\begin{tabular}{|c|c|c|c|}
\hline Turn & Time & Message & Translation \\
\hline 1 & $15: 32$ & Dong：明天就百日誓师了 & $\begin{array}{l}\text { Dong: Tomorrow will be } 100 \text { Daytime Countdown to the college } \\
\text { Examination. }\end{array}$ \\
\hline 2 & $15: 36$ & Lucetta: 同誓, 今晚（笑脸） & Lucetta: The same with us, tonight (smile) \\
\hline 3 & $15: 37$ & $\begin{array}{l}\text { Yun: 通知, 请高三各位班主任明天下午组 } \\
\text { 织学生到食堂顶楼参加倒计时 } 100 \text { 天动员 } \\
\text { 大会, } 2: 30 \text { 开始。这是我们学校的安排 }\end{array}$ & $\begin{array}{l}\text { Yun: Notice: please organize students to attend the 100-day } \\
\text { countdown meeting on the top floor of the dining hall tomorrow } \\
\text { afternoon, starting at 14:30. This the arrangement of our school. }\end{array}$ \\
\hline 4 & $15: 42$ & $\begin{array}{l}\text { Lucetta: 我们的好简单的, 喊喊口号, 各 } \\
\text { 代表发言, 然后签字, 好像没了 }\end{array}$ & $\begin{array}{l}\text { Lucetta: Ours is very simple: shout slogans, representatives speak, } \\
\text { then sign a paper, that's all. }\end{array}$ \\
\hline 5 & $15: 45$ & Bradley：然后学校管饭 & Bradley: And then the school pays for the meal. \\
\hline 6 & $15: 53$ & Kang：学校真好（赞） & Kang: Good school! \\
\hline 7 & 16:01 & $\begin{array}{l}\text { Maria: @Yun 食堂顶楼? 是食堂很大, 还 } \\
\text { 是学生很少? }\end{array}$ & $\begin{array}{l}\text { Maria: @ Yun On the top floor of the dining hall? Do you have a big } \\
\text { dining hall or a few students? }\end{array}$ \\
\hline 8 & $16: 11$ & John: @ Bradley 支持你的观点 & John:@Bradley I support your idea. \\
\hline 9 & $16: 18$ & Xin: 我们正在集合, 誓师大会 ing & Xin: We are gathering, the meeting is going on. \\
\hline 10 & $16: 42$ & $\begin{array}{l}\text { Yang: 老师们, 这篇完形填空的难度对高 } \\
\text { 三学生来说怎么样? }\end{array}$ & $\begin{array}{l}\text { Yang: Teachers, how about the difficulty of this cloze filling for } \\
\text { senior three? }\end{array}$ \\
\hline 11 & $16: 43$ & $\begin{array}{l}\text { Yang: 从 1-10 打分, } 1 \text { 分最容易, } 10 \text { 分最 } \\
\text { 难, 这篇完形的难度得几分? }\end{array}$ & $\begin{array}{l}\text { Yang: Rating from } 1 \text { to } 10,1 \text { is the easiest and } 10 \text { is the hardest. } \\
\text { How do you assess the difficulty? }\end{array}$ \\
\hline 12 & $16: 48$ & Rou: 我们今天也百日誓师了 & Rou: Today we have the meeting too. \\
\hline
\end{tabular}

The fact that turn-taking is significantly disrupted even in relatively "coherent" samples such as these (e.g. example 2) suggests that disruption of turn-taking is a real and persistent phenomenon in CMC.

\subsubsection{Overlapping exchanges}

As Herring (1999) has observed, overlapping exchanges are also characteristic of asynchronous group communication. Example 1 shows a high degree of overlap among exchanges: all three exchanges are "interrupted" by messages from the other two exchanges. Close parallel vertical lines in Figure 1 indicate multiple responses to a single message (e.g., message 1 (turn 1) received 13 responses, message 2 (turn 2 ) received 3 responses).

Three extended exchanges are interleaved in example 1, one topic about educational pressure, and the second about material sharing, and the third one about video sharing. These patterns of interaction can be represented schematically as in Figure 2. Different colors indicate different topics. Figure 1 shows clearly that exchanges overlap, rather than taking place in sequence - turns from one exchange regularly "interrupt" another. However, although three exchanges are overlapping with each other, involved participants or readers of messages could find the right responses to each topic by tracking the addressing tool "@” and adjacency pairs.

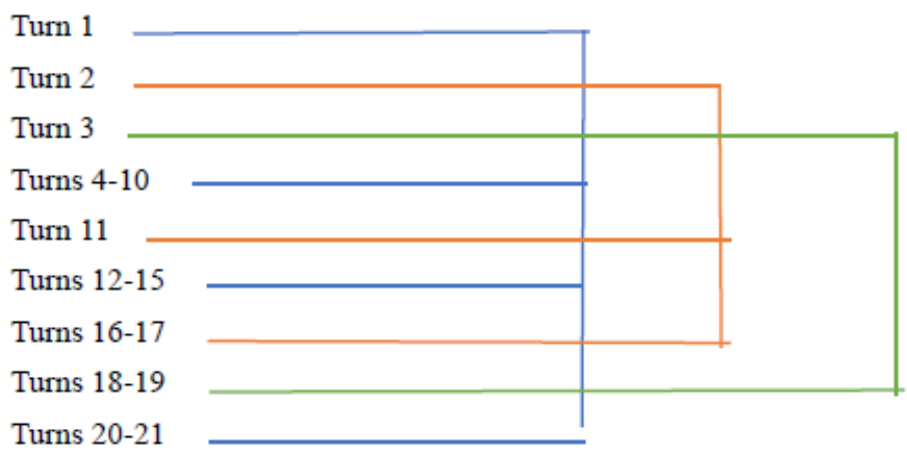

Figure 2. Schematic representation of interaction in a discussion (example 1) 


\subsubsection{Co-Constructed Conversational Floors}

Edelsky (1981) suggests that there are three definable elements to the floor: (1) the topic, the aboutness of the discourse; (2) the communicative action: how things are being said in the discourse; and (3) the participants' sense of what is happening in the conversation. Similarly, Shultz, Florio, and Erikson (1982) state, "the 'floor' is interactionally produced, in that speakers and hearers must work together at maintaining it" (p. 95). The two examples above have shown us how conversational floors, even overlapped floors, were co-constructed by multiple participants.

Simpson (2005) summarizes three habitually occurring floor types in CMC: speaker-and-supporter floor, collaborative floor, and multiple conversational floors. The researcher argues that all of these floor types are jointly constructed by participants or respondents. As Example 1 and figure 2 show, when two or more floors exist in parallel, multiple conversational floors are evident. Under this circumstance, the participants co-constructed individual conversational floor by responding to the turns which they were interested in and using a cohesive device, for instance, cross-turn reference (Herring, 1999) or addressivity.

\subsubsection{Topic Management and Development}

As Herring (1999) observed, when participants compose responses to a topic simultaneously, multiple competing new directions for discussion are introduced. As participants respond to others' responses, the chances that they will move further away from the original topic, as a result, new topics of discussion will arise and increase exponentially.

Example 3 is a relatively coherent interaction about educational problems in China. However, there were still unrelated adjacency pairs (e.g. turns 11,13,20,21). During the process of topic development, participants did not pay attention to the "interruption" and did not respond to the "newcomer". Furthermore, it seems that some respondents to the previous message even move further away from the original topic, for example, turn 15, Max moved away from the original topic [about English tutoring of their children] through introducing his own learning experience.

\subsection{Evidence for Formation of Virtual Community}

Guided by these six criteria summarized by Herring (2004), the researcher seeks to access whether the professional online group of EFL teachers can be called a "virtual" or an "online" community.

\subsubsection{Active Participation and a Core of Regular Participants}

According to Herring (2004), participation can be measured over time and core participants can be identified based on the frequency of posting. During the period of six months (180 days), there were 4622 conversational turns posted, on average there were about 27 turns every day. We have to consider another factor, the January and February were winter holidays in China, during the holidays there were fewer messages posted.

Example 3 (9th April 2019)

\begin{tabular}{|c|c|c|c|}
\hline Turn & Time & Message & Translation \\
\hline 1 & 19:07 & $\begin{array}{l}\text { Lucetta: 好郁问哦, 比较好的补习班, 听 } \\
\text { 写, 连个 opinion 都写不出来 }\end{array}$ & $\begin{array}{l}\text { Lucetta: It's depressing. In a good tutoring center, when dictating, } \\
\text { even doesn't know how to spell opinion. }\end{array}$ \\
\hline 2 & $20: 10$ & Rui:@Lucetta 怪你还没习惯！ & Rui:@Lucetta You are not used to it! \\
\hline 3 & $20: 42$ & $\begin{array}{l}\text { John:@Lucetta 还没修炼出来哦, 很正常, } \\
\text { 摆正心态 }\end{array}$ & John:@Lucetta You need to adjust yourself and your mind. \\
\hline 4 & $21: 15$ & $\begin{array}{l}\text { Dan:今晚辅导我妞学英语, 气的心肝脾肺 } \\
\text { 痛, 比较差生还气愤 }\end{array}$ & $\begin{array}{l}\text { Dan: Tonight I tutored my daughter to learn English. I got so angry. } \\
\text { It's even harder than teaching not so good students. }\end{array}$ \\
\hline 5 & $21: 18$ & Max:冷静 & Max: Calm down \\
\hline 6 & $21: 25$ & $\begin{array}{l}\text { John:@Dan 我女儿要读小学了, 估计我要 } \\
\text { 打人了, 耐心不够 }\end{array}$ & $\begin{array}{l}\text { John:@Dan My daughter will go to elementary school. I'm not very } \\
\text { patient, I think I will punish her. }\end{array}$ \\
\hline 7 & $21: 38$ & Wang: 还没上小学, 你教啥教 & Wang: Why do you teach her English before elementary school? \\
\hline 8 & $21: 40$ & Dan:英语还是要早点启蒙的 & Dan: It is necessary to teach English earlier. \\
\hline 9 & $21: 45$ & $\begin{array}{l}\text { Bai: 亲们别着急, 过来人经验, 慢慢就好 } \\
\text { 了。不能看前期, 入门后孩子学的很快 }\end{array}$ & $\begin{array}{l}\text { Bai: Don't worry. According to my experience, just take your time. } \\
\text { You can't focus only on the early stage, after the introduction, } \\
\text { children will learn quickly. }\end{array}$ \\
\hline
\end{tabular}


10 21:57 Max:我小学英语特别差, 上初中后就好起 Max: I did a bad job in elementary school, but after entering middle 来了, 后来就一直读英语专业, 直到现在 school I did better and better. So I chose English as my major, and 当了老师 then I became an English teacher.

11 21:59 Ping: 老师们, 请问大家有 Module 4 Ping: Teachers, who has the presentation of Module 4 Sandstorms in Sandstorms in Asia 的优质课件吗? Asia?

12 22:01 Max: 所以都是小学不用太着急, 但初中 Max: So don't hurry up in the elementary school, but the middle 蛮关键的 school is a key stage.

$1322: 02$ Ping:有的话, 麻烦分享一下

Ping: If you have, please share it.

$1422: 03$ Bai:不用太为难孩子, 慢慢会好起来的

Bai: Don't be too hard with your children, everything will be better.

15 22:04 Max:不过我也很感谢我的初中英语老师, Max: But I have to thank my English teacher in middle school, she 她抓得紧。 was very responsible.

Max: 所有的问题都是思想问题, 他不想 Max: All the questions resulted from ideology, if he doesn’t want to 学怎么都不行 learn, you can't help anything.

$1622: 05$ Bai:没错 Bai: That's right.

17 22:08 Lucetta:@John 道理听了很多, 可是还是难 Lucetta:@John I listened a lot, but it’s still hard to do that. 做到

18 22:09 Bai:自己孩子最是没耐心, 学生咱不敢发 Bai: We are the most impatient with our children. We can't get angry

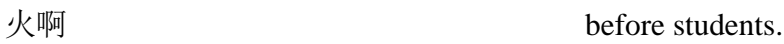

18 22:10 Lucetta:我也是觉得, 学生已经耗尽了我们 Lucetta: I think so. Students have exhausted all our patience, so I 所有的耐心, 所以我经常给孩子道歉 often apologize to my child.

20 22:24 Yan:能不能帮忙传下名词、冠词的专项 Yan: Who can help download the Section exercises for nouns and Section 习题? articles?

$2122: 25$ Yan:谢谢 Yan: Thanks.

22 22:28 Joe:@Lucetta (针对 turn18) 请问北京也用 Joe:@Lucetta (regarding turn 18) Do you use the PEP version (EFL 人教版吗? textbooks) in Beijing?

In addition, after checking the database, the researcher identified several regular participants, for example, Bradley, as the administrator of the group, posted 682 messages, some of them were purely shared information or learning materials; Mr. Ye has posted 488 messages, most of which were responded by other participants.

\subsubsection{Shared History, Purpose, Culture, Norms, and Values}

As examples 1, 2, 3 show, the high school EFL teachers shared some similar experiences or values. Firstly, they experienced various pressures both from school and families. When confronted with the exam-oriented education, they could not change anything, although they criticized the system. In addition, they have similar working experience, such as Gaokao (the College Entrance Examination). Thirdly, the Group has specific norms for participation and interaction, if some member posted something irrelevant or harmful for the country, the administrator has the right to kick him out or prohibiting speaking for some time.

\subsubsection{Solidarity, Support}

Most of the posted exchanges were knowledge sharing or advice seeking. For example, the most common sentence pattern was "Who can share...with me?" "Who can help me with the following question...?" As example 3 shows, when a member faced some kind of pressure or difficulty, other participants became more active to respond and post something optimistic and encouraging.

\subsubsection{Emergence of Roles, Hierarchy, Governance}

In this Group, there was an administrator (Bradley) who approves a new membership, monitors the group interaction and takes responsibility for members' comments and posts. In addition, there was hierarchy management according to the frequency of participating in the discussion and posting messages, such as newcomer, common member, assistant, intermediate, senior, etc. 


\subsubsection{Self-Awareness of Group as an Entity Distinct from Other Groups}

According to Herring (2004), a group's self-awareness can be manifested in its members' references to the group as a group, particularly in statements to the effect, "We do things this way here". For example, members often share interesting and educational videos, no matter what the original language is, they share videos only with English subtitles for the sake of learning. For example, when some teachers mentioned they provide tutoring service for payment during their holidays, others indicated "The ministry of education has repeatedly stressed that no after-class tutoring, we should not break the law."

In summary, to some extent, it seems that this online EFL teachers group can be seen as an online community, where members seek advice, learn from each other, express opinions about education, and share useful teaching resources.

\section{Discussion and Conclusion}

As Blitvich and Bou-Franch (2019) stated, "The group under scrutiny conforms an online community with no offline relationship and can, therefore, be associated with users that come together due to a shared interest but have very loose ties" (p. 14). Using principles of conversation analysis, the researcher has made an effort to identify the turn-taking structures of online discussion. As Tan and Tan (2006) have observed, turn-taking is complex in the online environment presented, carrying a somewhat "web-like and branching form" (p. 355). Specifically, in the online group, there could be multiple responses to one turn of talk, there could be more than one person 'talking' at the same time, in other words, members built on each other's responses. In addition, similar to Tan and Tan's (2006) findings in the research on online learning forums, members in this EFL Teachers Group could either choose to read what other members have presented and comment on them or ignore what has been discussed or shared.

Echoing to Herring's (1999) findings, in especially active multi-participant CMC, the effect of overlap and incomplete, redundantly-initiated exchanges can be likened to a "chaotic cocktail party" in which every conversation is taking place, equally loudly, in the presence of every guest (p. 4). The availability of a textual record of CMC makes participants aware of the processes of topic decay to a greater extent than they would be in more ephemeral modalities of communication.

This study has presented how computer-mediated discourse analysis was used to research virtual community and multiparty digital discourse features. Crucially, CMDA requires that the virtual community be operationalized according to behavioral criteria. On the Internet, such behavior takes place primarily through discourse. Although there is room for disagreement as to the best conceptualization of the virtual community, and operationalization should be plausible and measurable to be applied and interpreted (Herring, 2004).

The process of turn-taking and topic maintenance are subject to disruption and breakdown in computer-mediated environments, this finding echoes the findings of Herring (1999). While the researcher argues that text-only computer-mediated communication is interactionally coherent by presenting evidence that users employ adaptive turn-taking strategies to overcome interactional limitations of CMC systems, for example, through addressing the specific respondent or message, through using capture screen. This study shows that discourse measures are especially useful for analyzing community characteristics in different online environments. Further, once the virtual community has been identified by discourse-independent means in specific contexts, the discourse behaviors associated with it can be analyzed and extended as heuristics to identify a virtual community in other contexts (Herring, 2004).

The present study is not without limitations. For example, because of the limitation of space, the discourse strategies were not analyzed and identified in detail. The researcher argues that the future research should be addressed to more specific issues, such as interactional coherence of $\mathrm{CMC}$, topic development of $\mathrm{CMC}$, etc. With the increasing digitalization of the world and our daily life, it is necessary and valuable to do digital discourse research. Hence, much more work in this direction remains to be done.

\section{References}

Baron, N. S. (1998). Letters by phone or speech by other means: Te linguistics of email. Language and Communication, 18, 133-170. https://doi.org/10.1016/S0271-5309(98)00005-6

Baron, N. S. (2008). Always On: Language in an Online and Mobile World. Oxford: Oxford University Press. https://doi.org/10.1093/acprof:oso/9780195313055.001.0001

Bolander, B., \& Locher, M. (2010). Constructing identity on Facebook: report on a pilot study. In Junod, K., Maillat, D. (Eds), Performing the Self, (pp. 165-187). Tübingen: Narr Francke.

Champeon, H. C. (2010). Conversations within conversations: intertextuality in racially antagonistic dialogue on Usenet. Language@Internet, 7, article 10. Retrieved November 24, 2014, from

www.languageatinternet.org/articles/2010/2820

Cherny, L. (1999). Conversation and Community: Chat in a Virtual World. Stanford, CA: Center for the Study of 
Language and Information.

Condon, S. L., \& Čech, C. G. (2001). Profiling turns in interaction: Discourse structure and function. In Proceedings of the Thirty-Fifth Hawai'i International Conference on System Sciences. Los Alamitos, CA: IEEE Press.

Couper-Kuhlen, E., \& Selting, M. (2017). What is Interactional Linguistics? In Interactional Linguistics: Studying Language in Social Interaction (pp. 3-26). Cambridge: Cambridge University Press. https://doi.org/10.1017/9781139507318

Eckert, P., \& McConnell-Ginet, S. (1992). Think practically and look locally: Language and gender as community-based practice. Annual Review of Anthropology, 21, 461-490. https://doi.org/10.1146/annurev.an.21.100192.002333

Edelsky, C. (1981). Who's Got the Floor? Language in Society, 10(3), 383-421. https://doi.org/10.1017/S004740450000885X

Garcés-Conejos Blitvich, P., \& Bou-Franch, P. (2019). Introduction to Analyzing Digital Discourse: New Insights and Future Directions. In Bou-Franch P., \& Garcés-Conejos Blitvich, P. (Eds.), Analyzing Digital Discourse: New Insights and Future Directions (pp. 3-22). Switzerland: Palgrave Macmillan. https://doi.org/10.1007/978-3-319-92663-6_1

Georgakopoulou, A. (2006). Postscript: Computer-mediated communication in sociolinguistics. Journal of Sociolinguistics, 10(4), 548-557. https://doi.org/10.1111/j.1467-9841.2006.00292.x

Giles, D., Stommel, W., Paulus, T., Lester, J., \& Reed, D. (2015). Microanalysis of online data: the methodological development of "digital CA". Discourse, Context \& Media, 7, 45-51. https://doi.org/10.1016/j.dcm.2014.12.002

Goffman, E. (1967). Interaction Ritual: Essays on Face-to-Face Behavior. New York: Pantheon Books.

Gordon, C. (2004). 'Al Gore's our guy': linguistically constructing a family political identity. Discourse \& Society, 15(4), 607-631. https://doi.org/10.1177/0957926504045034

Graham, S. L. (2007). Disagreeing to agree: Conflict, (im)politeness and identity in a computer-mediated community. Journal of Pragmatics, 39, 742-759. https://doi.org/10.1016/j.pragma.2006.11.017

Greenfield, P. M., \& Subrahmanyam, K. (2003). Online discourse in a teen chatroom: New codes and new modes of coherence in a visual medium. Journal of Applied Developmental Psychology, 24(6), 713-738. https://doi.org/10.1016/j.appdev.2003.09.005

Gumperz, J. J. (2003). On the Development of Interactional Sociolinguistics. Language Teaching and Linguistic Studies, $1,1-10$.

Herring, S. C. (1999). Interactional coherence in CMC. Journal of computer-mediated Communication, 4(4). https://doi.org/10.1109/HICSS.1999.772674

Herring, S. C. (2004). Computer-mediated discourse analysis: An approach to researching online behavior. In Barab, S. A., Kling, R., \& Gray, J. H. (Eds.), Designing for Virtual Communities in the Service of Learning (pp. 338-376). New York: Cambridge University Press. https://doi.org/10.1017/CBO9780511805080.016

Herring, S. C. (2010). Computer-mediated conversation: introduction and overview. Language@Internet 7. Retrieved from http://www.languageatinternet.org/articles/2010/2801

Herring, S. C. (2019). The coevolution of computer-mediated communication and computer-mediated discourse analysis. In Bou-Franch P., \& Garcés-Conejos Blitvich, P. (Eds.), Analyzing Digital Discourse: New Insights and Future Directions (pp. 25-68). Switzerland: Palgrave Macmillan. https://doi.org/10.1007/978-3-319-92663-6_2

Herring, S. C., \& Androutsopoulos, J. (2015). Computer-Mediated Discourse 2.0. In Tanne, D., Hamilton, H. E., \& Schiffrin, D., The Handbook of Discourse Analysis (2nd ed.) (pp. 127-151). Oxford: WILEY Blackwell. https://doi.org/10.1002/9781118584194.ch6

Kozinets, R. V. (2010). Netnography: Doing Ethnographic Research Online. London: Sage Publications.

Labov, W. (1972). Language in the Inner City. Philadelphia: University of Pennsylvania Press.

Lipinski-Harten, M., \& Tafarodi, R. W. (2013). Attitude moderation: a comparison of online chat and face-to-face conversation. Computers in Human Behavior, 29(6), 2490-2493. https://doi.org/10.1016/j.chb.2013.06.004

Locher, M., \& Watts, R. J. (2005). Politeness theory and relational work. Journal of Politeness Research, 1(1), 9-34. https://doi.org/10.1515/jplr.2005.1.1.9

Mann, C., \& Stewart, F. (2000). Internet communication and qualitative research. London: Sage Publishers. 
https://doi.org/10.4135/9781849209281

Marcoccia, M. (2004). On-line polylogues: Conversation structure and participation framework in internet newsgroups. Journal of Pragmatics, 36(1), 115-145. https://doi.org/10.1016/S0378-2166(03)00038-9

Mesthrie, R. (ed.). (2011). The Cambridge Handbook of Sociolinguistics (Cambridge Handbooks in Language and Linguistics). Cambridge: Cambridge University Press. https://doi.org/10.1017/CBO9780511997068

Nishimura, Y. (2012). Puns in Japanese computer-mediated communication: Observations from misconversion phenomena. AAAI Fall Symposium: Artificial Intelligence of Humor.

Paccagnella, L. (1997). Getting the seat of your pants dirty: Strategies for ethnographic research on virtual communities. Journal of Computer-Mediated Communication, 3(1). https://doi.org/10.1111/j.1083-6101.1997.tb00065.x

Planchenault, G. (2010). Virtual community and politeness: the use of female markers of identity and solidarity in a transvestites' website. Journal of Politeness Research, 6, 83-103. https://doi.org/10.1515/jplr.2010.005

Sacks, H., Schegloff, E. A., \& Jefferson, G. (1974). A simplest systematics for the organization of turn-taking for conversation. Language, 50, 696-735. https://doi.org/10.1353/lan.1974.0010

Schegloff, E. A., \& Sacks, H. (1973). Opening up Closings, Semiotica, 8(4), 2. https://doi.org/10.1515/semi.1973.8.4.289

Schönfeldt, J., \& Golato, A. (2003). Repair in chats: A conversation analytic approach. Research on Language and Social Interaction, 36(3), 241-284. https://doi.org/10.1207/S15327973RLSI3603_02

Shultz, J. J., Florio, S., \& Erikson, F. (1982). Where's the Floor? Aspects of the Cultural Organisation of Social Relationships in Communication at Home and in School. In P. Gilmore, \& A. A. Glatthorn (Eds.), Children In and Out of School: Ethnography and Education (pp. 88-123). Washington DC: Center for Applied Linguistics.

Simpson, J. (2005). Conversational floors in synchronous text-based CMC discourse. Discourse Studies, 7(3), 337-361. https://doi.org/10.1177/1461445605052190

Stommel, W. (2008). Conversation analysis and community of practice as approaches to studying online community. Language@Internet, 5, article 5. Retrieved from http://www.languageatinternet.org/articles/2008/1537

Suler, J. (2004). The online disinhibition effect. CyberPsychology \& Behavior, 7(3), 321-326. https://doi.org/10.1089/1094931041291295

Tan, S., \& Tan, A. (2006). Conversational analysis as an analytical tool for face-to-face and online conversations. Educational Media International, 43(4), 347-361. https://doi.org/10.1080/09523980600926374

Tannen, D. (2005). Interactional sociolinguistics as a resource for intercultural pragmatics. Intercultural Pragmatics, 2(2), 205-208. https://doi.org/10.1515/iprg.2005.2.2.205

Tsai, W. H. S., \& Men, R. L. (2018). Social messengers as the new frontier of organization-public engagement: a WeChat study. Public Relations Review, 44, 419-429. https://doi.org/10.1016/j.pubrev.2018.04.004

Wardhaugh, R., \& Fuller, J. M. (2015). An Introduction to Sociolinguistics (7th ed.). Wiley-Blackwell.

Wenger, E. (1998). Communities of practice: Learning, meaning, \& identity. Cambridge: Cambridge University Press. https://doi.org/10.1017/CBO9780511803932

Wu, J. (2014). How WeChat, the most popular social network in China, cultivates wellbeing. Master of Applied Positive Psychology (MAPP) Capstone Projects. Retrieved from http://repository.upenn.edu/mapp_capstone/65

\section{Copyrights}

Copyright for this article is retained by the author(s), with first publication rights granted to the journal.

This is an open-access article distributed under the terms and conditions of the Creative Commons Attribution license which permits unrestricted use, distribution, and reproduction in any medium, provided the original work is properly cited. 